\title{
FUNGSI DAN MAKNA SIMBOL-SIMBOL DALAM PALINGGIHPADMASANA PERSPEKTIF KAJIAN BUDAYA
}

\author{
Anak Agung Gde Putera Semadi \\ Fakultas Hukum Universitas Dwijendra \\ Email: puterasemadi60@gmail.com
}

\begin{abstract}
ABSTRAK
Palinggih Padmasana merupakan bangunan suci untuk memuja Ida Sang Hyang Widhi Wasa / Tuhan Yang Maha Esa dalam berbagai manifestasinya. Ia tidak hanya memiliki bentuk yang berbeda-beda, tetapi juga sebutan, fungsi, dan makna simbol-simbol yang berbeda berdasarkan lokasinya. Secara sejarah, keberadaan palinggih ini baru dikenal sekitar abad ke-15 khususnya pada masa pemerintahan Dalem Waturenggong yang ditandai dengan datangnya seorang pendeta Shiwa yang sakti ke Bali bernama Danghyang Dwijendra dengan misi suci menyempurnakan tatanan kehidupan umat Hindu dari Tri Murti. untuk konsep Tri Purusa. Setiap fungsi dan lambang padmasana palinggih benar-benar mencerminkan kemuliaan makna yang tak ternilai, oleh karena itu Padmasana merupakan lambang alam semesta bagi umat Hindu. Melalui perspektif sistem budaya yang disertai dengan penerapan metode analisis deskriptif, topik penelitian ini berhasil dikaji secara kritis, logis, dan sistematis.

Kata Kunci: Fungsi, Makna Simbol, Padmasana
\end{abstract}

\begin{abstract}
Palinggih Padmasana is a sanctified building to worship Ida Sang Hyang Widhi Wasa/God Almighty in His various manifestations. It does not only has a varying fomrs, but olso defferent designation, function, and meaning of symbols which differ based on its location. Historycally, the existence of this palinggih was only known around 15th century especially during the reigin of Dalem Waturenggong which was indicated by the arrival of a powerful Shiwa priest to Bali named Danghyang Dwijendra with a sacred mission of perfecting the order of Hindu life from Tri Murti to Tri Purusa concept. Each function and symbol in palinggih Padmasana truly reflects the nobility of invaluable meaning, therefore, Padmasana is a symbol of the universe for Hindus. Through the perspective of cultural sytudies which is accompained by the implementation of descriptive analysis method, this research topic was successfully studied critically, logically, and systematically.
\end{abstract}

Keywords: Function, Meaning of symbol, Padmasana.

\section{PENDAHULUAN}

Terminologi Padmasana mulai dikenal pada zaman pemerintahan Dalem Waturenggong sekitar abad ke-15 ditandai dengan kedatangan Danghyang Dwijendra atau disebut juga Danghyang Nirarta ke Bali. Pada saat itu Beliau membawa misi suci: "Ingin menyempurnakan konsepsi Tri Murti yang diajarkan Mpu Kuturan menuju ke arah konsepsi Tri Purusa”. Tri Murti bersifat horisontal dengan Brahma-Wisnu-Siwa, sedangkan Tri Purusa bersifat vertikal dengan Parama Siwa-Sada Siwa, dan Siwa. Konsepsi Lingga yang dikenal sebagai perwujudan dari Siwa (Tuhan Yang Maha Esa) adalah lahir dari perpaduan kedua konsepsi ini. Menurut Widana (1997), Purusa mengajarkan 
pemujaan Tuhan menurut sifatnya dan menuju ke arah "ke-Esa- an-NYA". Suatu bangunan yang kemudian dikonsepsikan untuk memuja Tuhan Yang Maha Esa itulah oleh Danghyang Dwijendra diperkenalkan sebagai Padmasana.

Padmasana adalah bangunan suci (palinggih) bebaturan menyerupai candi namun tidak beratap, yang difungsikan untuk sthana Ida SangHyang Widhi Wasa, dan sering dijumpai sebagai palinggih utama di kahyangan-kahyangan jagat, serta parhyangan lainnya. Menurut Mojowasito (1977), kata Padmasana berarsal dari bahasa Kawi yang terdiri atas dua kata yaitu Padma dan Asana. Padma artinya bunga teratai, atau batin, atau pusat. Sedangkan Asana artinya sikap duduk, atau tuntunan, atau juga nasehat, dan perintah.

Padmasana merupakan palinggih sentral tempat memuja Tuhan Yang Maha Esa sebagai simbol atau penggambaran dari alam makrokosmos (alam semesta). Secara historis bangunan palinggih Padmasana sebagai simbol alam semesta dapat dilihat dalam lontar Dwijendra Tattwa. Lontar tersebut menjelaskan bahwa bangunan suci Padmasana dikembangkan oleh Danghyang Dwijendra (Dangyang Nirarta). Beliau datang ke Bali pada tahun 1489 M, tepatnya pada periode pemerintahan Dalem Waturenggong di Gelgel (1460-1550). Sebagaimana telah diuraikan di atas bahwa misi Beliau datang ke Bali adalah untuk menyempurnakan tatanan kehidupan beragama Hindu melalui konsepsi Tri Murti menuju ke arah konsepsi Tri Purusa. Tuhan Yang Maha Esa yang tidak terdefinisikan dengan apapun atau tanpa atribut apapun disthanakan (ditempatkan) di palinggih Padmasana.
Bangunan palinggih Padmasana memilkiki beragam simbol dan keartistikan makna yang sangat dalam, sehingga sangat menarik untuk dikaji secara mendalam melalui paradigma kajian budaya keritis.. Berdasarkan pertimbangan tersebut, maka hasil penelitian ini menjadi sangat penting dihadirkan, apalagi di dalam hasil penelitian ini dapat disimak satu analisis yang tajam, mendalam, kritis, dan sistematis yang berhubungan dengan bentuk, fungsi, serta makna dari bangunan palinggih Padmasana sebagai tempat suci untuk memuja keESA-an Ida Sang Hyang Widhi Wasa, Tuhan Yang Maha Esa.

\section{METODE}

Bentuk penelitian culture studies ini dirancang sebagai penelitian kualitatif dengan pendekatan penomenologis yang mengutamakan kajiannya pada permasalahan teks serta konteksnya ada di masyarakat. Penelitian kualitatif tergolong sebagai prosedur penelitian yang menghasilkan data deskriptif berupa kata-kata serta data berupa gambar yang dapat diamati dan dideskripsikan dengan jelas tanpa menggunakan prosedur-prosedur statistk atau dengan cara kuantifikasi lainnya.

Penelitian ini tidak menggunakan hipotesis.

Semua data lapangan serta hasil studi pustaka yang telah diklasifikasi dikaji dengan menggunakan teori Semiotika dari C.S. Peirce Untuk memeroleh hasil pemaparan yang tajam, logis, dan sistematis, maka aplikasi metode analisis deskriptif jelas tidak dapat dihindari. Penentuan informan dilakukan dengan teknik purposive random sampling dan dikembangkan dengan teknik snowball. Sumber data diperkuat dengan instrumen penelitian berupa 
pedoman observasi partisipasi, pedoiman wawancara mendalam, rekaman, serta studi dokumen.

\section{HASIL DAN PEMBAHASAN}

\section{Fungsi Palinggih Padmasana}

Palinggih Padmasana hampir dapat ditemukan dalam setiap tempat suci di Bali, demikian pula halnya dengan di laur Bali, misalnya di pulau Jawa. Dalam paradigma historis, dapat disebutkan bahwa sebelum datangnya Danghyang Dwijendra ke Bali, tatanan kehidupan beragama Hindu di Bali sudah demikian baik. Pada saat itu masyarakat memuja para Dewa/i sebagai manifestasi dari Tuhan. Kemudian setelah kedatangan Beliau sistem pemujaan Hindu ditata untuk menjadi lebih baik lagi dengan cara melengkapi palinggih-palinggih yang sudah ada itu dengan mendirikan satu bangunan lagi yakni berupa palinggih yang disebut Padmasana.

Secara elementer palinggih Padmasana berfungsi untuk memuja Tuhan yang tak terpikirkan (acintya) atau yang tanpa sifat, tanpa wujud (nirgunam Brahman), bukan Tuhan yang berwujud (sagunam Brahman). Sandika (2011:82) menyebutkan bahwa Tuhan yang sagunam dapat dipuja oleh umat berupa simbol yang disthanakan di palinggih-palinggih tertentu, tetapi di dalam palinggih Padmasana Tuhan tidak disimbolkan dengan apapun. Sehingga di bagian atas bangunan palinggih Padmasana tidak disthanakan wujud Tuhan dalam bentuk apapun melainkan hanyalah kosong/nol. Kekosongan atau alam trancenden (sunya) itu merupakan alam Brahman, alam tersebut berada di luar batas lingkaran pikiran manusia.
Alam kosong itulah yang kemudian disimbolkan dengan palinggih Padmasana, dan yang menjadi tujuan akhir hidup sebagai manusia Hindu (moksartham). Sesungguhnya menyadarkan manusia akan hakikat keberadaan alam semesta beserta isinya (Santika, 2019), termasuk keberadaan manusia itu sendiri adalah bagian dari eksistensi fungsi bangunan palinggih Padmasana. Manusia disadarkan tentang tujuan hidupnya selama di dunia ini serta ke arah mana tujuan hidupnya itu setelah meninggalkan dunia ini. Secara hirarki semua yang ada karena berawal dari ketiadaan (kosong), kemudian menjadi ada, dan semua yang ada inipun akhirnya akan kembali lagi ke ketiadaan (kosong) itu. Eksistensi dari semua ini mengalami utpeti, sthiti, dan pralina (proses lahir, hidup, dan kemudian mati).

Secara filosofis Padmasana itu adalah lambang alam semesta, linggih Sanghyang WidhiTuhan Yang Maha Esa yang sebenarnya. Selain besifat Esa (adwityam), Beliau juga bersifat tak terpikirkan (acintya). Itulah sebabnya pada bagian puncak Padmasana dilengkapi dengan relief Acintya atau Sanghyang Licin. Jika dalam konsepsi Tri Murti di mana Tuhan dipuja menurut fungsinya, Brahma-Wisnu-Siwa dapat dirupakan atau digambarkan, maka dalam konsepsi Tri Purusa yang memuja Tuhan menurut sifatnya, Tuhan sama sekali tidak patut digambnarkan atau diarcakan lagi.

Menurut lontar Catur Wariga Winasasari (lihat Widana,1997:28) Jenis bangunan palinggih Padmasana dapat disebutkan berdasarkan letaknya yaitu :

1. Padmakencana = terletak di timur menghadap ke arah barat 
2. Padmasana = terletak di selatan menghadap ke arah utara

3. Padmasari = terletak di barat menghadap ke arah timur

4. Padmasana Lingga $=$ terletak di utara menghadap ke arah selatan

5. Padma Asta Sedana $=$ terletak di tenggara menghadap ke arah barat laut

6. Padmanoja = terletak di barat daya menghadap ke arah timur laut

7. Padmakaro= terletak di baratlaut menghadap ke arah tenggara

8. Padmasaji = terletak di timurlaut menghadap ke arah baratdaya

9. Padmakurung = terletak di tengah marong tiga menghadap ke arah lawangan (pintu ke luar).

Apabila ditinjau dari rong dan pepalihannya (ruang dan undag/tingkatannya), maka jenis Padamsana itu dapat disebutkan sebagai berikut:

1. Padmasana Anglayang, marong tiga (tiga ruang), menggunakan Bedawang Naladengan palih pitu (tujuh tingkat)

Padma Agung, marong kalih (dua ruang), menggunakan Bedawang Nala dengan palihlima (lima tingkat)

2. Padmasana, marong siki (satu ruang), menggunakan Bedawang Nala dengan palihlima (lima tingkat)

3. Padmasari, marong siki (satu ruang) dengan palih tiga (tiga tingkat) yaitu palih taman(bawah), palih sancak (tengah), dan palih sari (atas), tidak menggunakan Bedawang Nala.

4. Padma Capah, marong siki (satu ruang) dengan palih kalih (dua tingkat) yaitu palihtaman (bawah) dan palih capah (atas), tidak menggunakan Bedawang Nala.

Fungsi palinggih Padmasana berbeda menurut tempatnya, misalnya: Padmasana yang terletak di arah timur sebagai linggih Ida Sanghyang Iswara, yang terletak di arah selatan sebagailinggih Ida Sanghyang Brahma, di arah barat sebagai linggih Ida Sanghyang Mahadewa, di arah utara sebagai linggih Ida Sanghyang Wisnu, di arah timur laut sebagai linggih Ida Sanghyang Siwa Raditya, di arah tenggara sebagai linggih Ida Sannghyang Mahesoara/Maheswara, di arah barat daya sebagai linggih Ida Sanghyang Rudra, dan di arah baratlaut sebagai linggih Ida Sanghyang Sangkara. Sedangkan yang terletak di tengah-tengah disebut Padmakurung memakai rong tiga/telu (terdiri atas tiga ruang) di puncaknya sebagai linggih Ida Bhatara Samodaya. Berkaitan dengan Padmakurung ini, Arga Uthama dalam bukunya Seri 1 Arsitektur Tradisonal Bali Filosofi, Konsep, dan Aplikasi (2015:158) menyebutkan bahwa letak Padmakurung itu juga biasanya berada di tengah-tengah bangunan Palinggih lainnya, atau sering juga di bagian depan dari bangunan Meru atau Gedong yang berjejer secara horizontal seperti yang ada di Pura Taman Ayun, Pura Puncak Mangu Tinggan, Pura Beratan Besakih dan lain sebagainya.

Padmasari dan Padmacapah dapat ditempatkan menyendiri dan berfunhgsi sebagai pangayatan/panyawangan. Mengenai padagingan kedua Padmasana ini hanya pada dasar dan Puncak 
saja. Sedangkan Padmasana yang menggunakan Bedawang Nala berisi padagingan

Pada dasar, madya (tengah), dan puncak (Widana, 1997:28).

\section{Makna Simbol-Simbol Padmasana}

Tatacara mendirikan bangunan palinggih Padmasana adalah berpijak pada Lontar Asta Kosala-Kosali dan Asta Bhumi. Dalam lontar-lontar itu sama sekali tidak ada disebutkan tentang perlunya menyertakan sebuah arca pada singgasana Padmasana. Atribut yang melengkapi bangunan palinggih Padmasana itu adalah Bedawang Nala (simbol magma bumi) yang dililit naga Ananta Bhoga (simbol bumi) dan naga Basuki (sebagai simbol air). Pada bagian belakang Padmasana terdapat relief Garuda (simbol pembebasan), dan Angsa (sebagai simbol kebijaksanaan serta kesucian). Apabila ditemukan ada arca pada puncak bangunan palinggih Padmasana, maka jelas perkembangan konsep itu tidak berdasarkan sumber lontar-lontar yang telah disebutkan di atas itu.

Dalam buku Acara III (1985:20-21) disebutkan bahwa Padmasana dalam pengertian agama Hindu adalah suatu simbolis daripada sthananya (linggih) SangHyang Widhi yang berbentuk bangunan menjulang tinggi. Di ekonografi dewa-dewa Hindu dilukiskan sebagai arca duduk di atas bunga teratai. Patung Dewa di atas bunga teratai banyak dijumpai pada zaman Kediri, Singosari, dan Majapahit.

\section{Bunga Teratai}

Bunga teratai berhelai delapan dipandang sangat tepat digunakan sebagai simbol Asta Aiswarya yang menguasai delapan penjuru mata angin. Bunga teratai hidup dalam tiga lapisan alam yaitu akarnya di lumpur, daunnya di air, dan bunganya di udara. Oleh karena itu bunga teratai disebut juga Pangkaja artinya lahir dari lumpur. Dalam kitab-kitab Purana disebutkan para Dewa muncul dari Padmasana. Padmasana ini adalah lambang gunung Maha Meru atau lambang alam semesta tempat Ida Sang Hyang Widhi bersthana. Padmasana dalam arti arafiah adalah bunga padma yang dianggap sebagai linggih Ida Sang Hyang Widhi Wasa.

Dalam kaitannya dengan ngalinggihang (menstanakan) Ida Sang Hyang Widhi Wasa di palinggih Padmasana, ada baiknya sangat perlu diperhatikan puja Pendeta Siwa atau Budha (dalam buku Acara III, 1985:22) seperti di bawah ini

\section{Puja Pendeta Siwa}

Om Om Kurmagni ya namah Om Om Anantasana ya namah Om Om Catur Aiswarya ya namahOm

Om Padmasana ya namah Om Om Pratista ya na

\section{Puja Pendeta Budha}

Om Om Kurmagni ya namah Om Om Anantasana ya namahOm Om Singasana ya namah Om Om

Padmasana ya namahOm Om Dewasana ya namah Catur Aiswasrya adalah puja Siwa sama dengan Singasana dalam puja Budha. Demikian pula Pratista dalam puja Siwa sama dengan Dewasana dalam puja Budha. Puja-puja tersebut adalah puja Ida Pedanda untuk membuat Padmasana dalam wujud mantra.

Dalam baris pertama dari Puja di atas disebutkan bahwa Kurmagni pada bangunan palinggih Padmasana adalah sebagai Bedawang Nala (Bedawang Api), yang kemudian menjadi dasar bangunan Padmasana.

Dalam baris kedua, disebut Anantasana yang 
artinya segitiga. Dalam palinggih Padmasana diwujudkan sebagai dua ekor naga melilit Kurmagni. Kalau diperhatikan dalam Lontar Sri Purwana Tattwa dan Siwagama dikuliskan adanya tiga ekor naga penjelmaan Sang Hyang Tri Murti dalam menyelamatkan manusia dari penderitaan. Brahma menjelma menjadi Naga Anantha Boga, Wisnu menjelma menjadi Naga Basuki, dan Iswara menjelma menjadi Naga Taksaka.

Dalam baris ketiga, disebutkan Singsana dan Catur Aiswarya disimbolkan sebagai bentuk kursi kebesaran.

Kemudian dalam baris keempat dan kelima masing-masing disebut Padmasana dan Dewasana, keduanya inilah yang tidak dilukiskan dalam bangunan palinggih Padmasana.

\section{Garuda}

Di belakang bangunan palinggih Padmasana terdapat hiasan burung Garuda terbang yang dilambangkan sebagai perjuangan untuk mendapatkan kebebasan dengan mencari air kehidupan (amerta). Cerita tentang burung Garuda ini dapat dijumpai dalam kitab Adiparwa ( parwa pertama dari kitab Asta Dasa Parwa, yaitu 18 parwa dalam kitab Mahabharata). Dalam kitabitu disebutkan Garuda anak Dewi Winata yang membebaskan ibunya dari perbudakan naga. Garuda adalah lambang manusia yang berjuang di alam ini untuk mencari amerta atau kebebasan yang abadi. Dalam Dwijendra Tattwa, disebutkan bahwa Garuda dalam palinggih Padmasana adalah simbol manusia yang menginginkan kebebasan melalui pelepasan dari keterikatan duniawi yang telah menyebabkan penderitaan. Oleh karena itu, makna ornamen burung Garuda dengan sayap terkepak adalah simbolisasi dari pelepasan. Simbol tersebut pula dapat mengingatkan umat Hindu bahwa kelepasan/kebebasan hendaknya menjadi tujuan hidup tertinggi dalam hidup ini ( $m o k s a)$.

\section{Angsa}

Selain burung Garuda, pada belakang bangunan palinggih Padmasana juga terdapat ornamen burung Angsa. Menurut Titib (2001:108) burung Angsa adalah lambang dari jiwa (soul atau roh), yakni suksma sarira yang membungkus atma. Sandika (2011:90) memaparkan bahwa berdasarkan pada kitab-kitab Upanisad. Burung Angsa yang mengepakkan sayapnya menggambarkan atman yang ingin bersatu dengan Brahman. Angsa juga dapat ditemukan dalam wadah (bade) sebagai simbol dari manusia (roh/atman) yang ingin kembali kepada Tuhan (amoring Acintya).

Dalam lontar Indik Tetandingan (perhatikan buku Acara III, 1985:24) terdapat keterangan bahwa lukisan angsa adalah simbol Ongkara. Kedua sayapnya melukiskan ardha chandra (bulan sabit). Badannya yang bulat dilukiskan sebagai windu, serta kepalanya yang mendongak ke atas adalah simbol nada.

\section{Acintya}

Simbol lainnya yang sangat penting untuk diumaknai adalah simbol Acintya. Pada bangunan palinggih Padmasana relief acintya tidak lain adalah simbol dari Tuhan Yang Maha Esa yang nirgunam. Dalam Brahmawidya (Teologi Hindu) dijelaskan bahwa Tuhan yang berada dalam tatanan nirgunam adalah Tuhan yang tanpa atribut, Tuhan yang trancendent, Tuhan yang tidak dapat dipikirkan (acintya), tidak berupa apapun (nirupam) dan lain-lain. Naiti-naiti (bukan ini, bukan pula itu). 
Relief atau ukiran Sang Hyang Acintya merupakan penggambaran dari Dewa Siwa dal;am menciptakan kosmos ini melalui tarian kosmik yang disebut dengan tarian Siva Nataraja. Dewa Siwa dengan kekuatan-Nya mewujudkan diri Beliau sebagai Siwa rajanya penari. Sebagai raja penari kosmis, Siwa adalah dewa pencipta sekaligus dewa pelebur ritme abadi alam semesta lewat tariannya. Beliau pada saat menari dilingkari oleh api, melambangkan proses hidup dari penciptaan alam semesta. Mudra gerak tangan-Nya melambangkan kegiatan-kegiatan yang berbeda. Dewa Siwa bertangan empat, dalam satu tangan-Nya memegang gendang (damaru), dan tangan-Nya yang kedua menunjukkan Abhaya Mudra yang berarti: "jangan takut, Aku (Siwa) akan melindungimu”. Dalam telapak tangan-Nya yang ketiga mengeluarkan lidah api sebagai simbol peleburan (bukan perusak). Kemudian tangan-Nya yang keempat menunjuk pada kakinya yang terangkat, melambangkan keselamatan bagi para pemuja-Nya. Di Bali Siwa Nataraja ini disimbolkan dengan Sang Hyang Acintya sebagai Dewa yang menciptakan alam kosmik (Sandika, 2011:91).

\section{Bedawang Nala}

Ornamen berupa Bedawang Nala yang dibelit oleh dua ekor naga yakni naga Anantha Boga dan naga Basuki terletak pada dasar bangunan palinggih Padmasana. Bedawang Nala (kura-kura raksasa) merupakan penggambaran dari keagungan Dewa Wisnu sebagai awatara yang memiliki misi khusus untuk menyelamatkan bumi dari kehancuran. Penjelmaan Dewa Wisnu mengambil wujud kurma (Kurma Awatara) adalah ketika diaduknya samudera mantana oleh para Dewa dan asura untuk mendapatkan amerta (air keabadian).

$$
\text { Gunung Mandara (Mandara Giri) }
$$

digunakan sebagai tongkat dalam mengaduk lautan. Vali sebagai raja asura dangan para asuranya dan Indra sebagai raja para dewa dengan dewa- dewa lainnya tampak begitu bersemagat sekali. Oleh karena itulah, maka bumi menjadi terguncang. Melihat hal tersebut, maka dengan kekuasaan-Nya Dewa Wisnu menjelma menjadi seekor kura-kura raksasa untuk menopang gunung supaya bumi tetap seimbang. Sandika menyebutkan bahwa Bedawang Nala (kura-kura) adalah simbol dari dasar alam, atau dapat pula diterjemahkan inti dari bumi. Dengan kata lain Bedawang Nala adalah dapur magma inti bumi atau energi kekuatan kehidupan. Energi alam hendaknya dimamfaatkan dan dikelola sebaik- baiknya karena semua itu adalah anugerah Tuhan untuk kelangsungan hidup manusia dan mahluk hidup lainnya.

Selain kedua ekor naga yang telah disebutkan di atas masih ada satu ekor naga lagi yang terdapat pada bagunan palinggih Padmasana, yaitu Naga Taksaka. Jadi ketiga ekor naga tersebut (Naga Anantha Boga, Naga Basuki, dan Naga Taksaka) merupakan sombolisasi dari elemen tanah, air, dan udara. Dalam Lontar Purwa Bumi Kemulan diceritakan umat manusia di bumi ini amat resah karena tanahnya tidak lagi subur unrtuk menumbuhkan tumbuh-tumbuhan, air amat kotor dan tidak dapat membersihkan badan kalau dipakai mandi. Demikian pula udara sangat kotor penuh dengan penyakit. Lalu atas permohonan Bhagawan Manu, maka Sang Hyang Tunggal menugutus Sang Hyang Tri Murti turun ke dunia untuk menyelamatkan alam sumber kehidupan 
manusia. Sang Hyang Brahma turun ke bumi menjlema menjadi Naga Anantha Boga. Sang Hyang Wisnu menjelma menjadi seekor Naga Basuki, dan Sang Hyang Iswara turun ke bumi menjelma menjadi Naga Taksaka. Masing-masing naga itu memiliki fungsi yang berbeda- beda. Naga Anantha Boga terus masuk ke dalam bumi membersihkan tanah dari segala kekotoran. Naga Basuki kepalanya masuk ke laut dan ekornya menjadi gunung. Air laut diuapkan menjadi mendung yang menyebabkan turun hujan. Air inilah yang kemudian mengalir menjadi sungai turun ke daerah-daerah pertanian untuk menyuburkan tanah. Sedangkan Naga Taksaka yang bersayap dan terbang di angkasa membersihkan udara dari polusi (Wiana, 1992).

Tentunya dalam bangunan palinggih Padmasana masih banyak terdapat ornamen yang tidak kalah pentingnya sebagai simbol kesucian yang sarat makna. Ornamen-ornamen tersebut memiliki hubungan timbal balik yang tak terpisahkan dari yang satu dengan yang lainnya. Kalau dipandang dari segi ketinggian bangunan palinggih Padmasana masih terdapat beragam variasi. Hal ini tidak lepas didasari oleh situasi dan kondisi loka dresta yang berkaitan dengan konsepsi filosofis Tri Hita Karana dan Desa Kala Patra. Walaupun terdapat sedikit perbedaan mengenai bentuk dan ketinggian serta kelengkapan ornamen dalam bangunan palinggih Padmasana, itu tidak akan mengurangi kehakikian fungsi dan maknanya sebagai simbol alam semesta, bangunan palinggih suci Ida Sang Hyang Widhi Wasa/Tuhan Yang Maha Esa.

\section{PENUTUP}

\section{Simpulan}

Secara historis bangunan palinggih Padmasana sebagai simbol alam semesta dapat dilihatdalam lontar Dwijendra Tattwa. Palinggih ini dikembangkan oleh Danghyang Dwijendra (Danghyang Niararta) ketika datang ke Bali pada pemerintahan DalemWaturenggong di Gelgel abad ke-15 (sekitar tahun 1460-1550). Misi kedatangan Beliau itu sangat mulia dan suci yakni ingin menyempurnakan tatanan kehidupan beragama Hindu di Bali, dan menyempunakan konsepsi Tri Murti menuju ke arah konsepsi Tri Purusa yang diajarkan oleh Mpu Kuturan.

Secara garis besar Padmasana dapat dibedakan berdasarkan atas lokasi dan rong (ruangnya). Menurut lontar Wariga Catur Winasasari, maka Padmasana berdasarkan jenis dan lokasinya ditentukan menurut pangider-ider sehingga terdapat sembilan jenis Padmasana (Padmakencana, Padmasana, Padmasana Sari, Padmasana Lingga, Padma Asta Sedana, Padmanoja, Padmakaro, Padmasaji, dan Padmakurung). Sedangkan yang berdasarkan atas rong (ruang) terdapat lima jenis Padmasana (Padmasana Anglayang, Padma Agung, Padmasana, Padmasari, dan Padmacapah). Tatacara pendirian bangunan palinggih Padmasana berpijak pada Lontar Asta Kosala-Kosali dan Asta Bumi.

Hiasan-hiasan yang terdapat dalam bangunan palinggih Padmasana seperti Sang Hyang Acintya, Burung Angsa, Burung Garuda, Bedawang Nala yang dibelit naga Anantha Boga, NagaBasuki, dan Naga Taksaka, termasuk bunga padma/teratai yang menjadi dasar palinggih, semuanya itu 
merupakan simbol suci yang memiliki fungsi dan sarat makna spiritual.

$$
\text { lontar Purwa Bumi Kemulan yang }
$$

menyebutkan tujuan penjelmaan para Dewa menjadi tiga ekor naga yang ada di bangunan palinggih Padmasana, dapat diartikan memiliki nilai pendidikan yang sangat baik dan tinggi serta relevan sekali dalam konteks kekinian. Semua itu bertjuan agar dapat memotivasi umat Hindu dalam melestarikan alam beserta isinya.

\section{DAFTAR PUSTAKA}

Arga Uthama, Ida Bagus. 2015. Seri 1 Arsitektur Tradisonal Bali Filosofi, Konsep, dan Aplikasi. Surabaya : Penerbit Paramita.

Bagus Sugriwa, I Gusti. 1993. Dwijendra Tattwa. Denpasar: PT. Upada Sastra Gambar, M. tt. Asta Bumi, Asta Kosala-Kosali, Umah Miwah Wadah

Gunawan, Kt. Pasek. 2012. Siva Siddhanta. Tattwa dan Filsafat. Surabaya: Paramita.

Made Ngurah, I Gusti. Agama Hindu Untuk Perguruan Tinggi. Surabaya: Penerbit Paramita. Lilis, 1995. "EraWaturenggong Renaisance Budaya Bali”. Denpasar: Bali Post, 4 Pebruari 1995Putra, tt. Cudamani.
Kumpulan Kuliah-Kuliah Agama Hindu.

Radhakrisna, 1989. Upanisad Utama. TerjemahanYayasan Parijata. Jakarta: Yayasan DharmaSarati.

Sandika, I Ketut. 2011. Pratima Bukan Berhala. Pemujaan Tuhan Melalui Simbol-Simbol SuciHindu.. Surabaya: Paramita.

Santika, I. G. N., Rindawan, I. K., \& Sujana, I. G. (2019). Memperkuat Pancasila Melalui Pergub No. 79 Tahun 2018 Dalam Menanggulangi Pengikisan Budaya Di Era Revolusi Industri 4.0. Prosiding Seminar Nasional Inobali 2019, 79, 981990

Santika, I. G. N. (2018). Strategi Meningkatkan Kualitas SDM Masyarakat Desa Padangsambian Kaja Melalui Pendidikan Karakter Berbasiskan Kepedulian Lingkungan Untuk Membebaskannya Dari Bencana Banjir. Widya Accarya. 9 (2).

Wiana, Ketut. 1993. Bagaimana Umat Hindu Menghayati Tuhan. Denpasar: Manik Geni. Wiana, Dkk. 1985. Aacara III. Jakarta: Mayasari.

Widana, I Gusti Ketut. Menjawab Tantangan Umat. Denpasar: Yayasan Dhar ma Narada. 